\title{
Editorial
}

\section{Cancer in the elderly}

The population in developed countries is aging and the proportion of higher age categories in the age structure is increasing. In the Czech Republic inhabitants aged over 70 years represented $7 \%$ of population in the year 1970, 10\% in the year 2009 and the expectation for the year 2030 is $25 \%$. This percentage is even higher in more developed countries in Europe and in the USA. The aging of the population unavoidably leads to a growing number of persons diagnosed and living with cancer (Table 1). With improving treatment and better survival of cancer patients also the number of second and third malignancies is rising (Fig. 1). The dynamics of incidence of the most frequent malignant tumors in patients older than 70 years is shown in Fig. 2. These patients represent $30-60 \%$ of newly diagnosed malignancies and an even higher percentage of the cancer death rate. The disease stages at diagnosis in patients aged $70+$ are shown in Fig. 3.
Growing incidence and mortality of malignant diseases in elderly patients together with an aging population brings new, urgent problems into daily oncological practice. Already some past articles in the Reports of Practical Oncology and Radiotherapy have been devoted to this topic. ${ }^{1}$ The present special issue is concentrated on some important aspects of this subject.

Elderly people frequently suffer due to cardiovascular disorders (myocardial infarctions, ischemic coronary disease with reduction of left ventricular function), pulmonary disorders (changes in ventilation and perfusion, chronical obstructive and restrictive changes), nephrologic and urologic complications, decreased bone marrow reserves, and nutrition problems. Comorbidity in these patients has a deep impact on the tolerance of all principal methods of oncological treatment - surgery, radiotherapy and medical therapy.

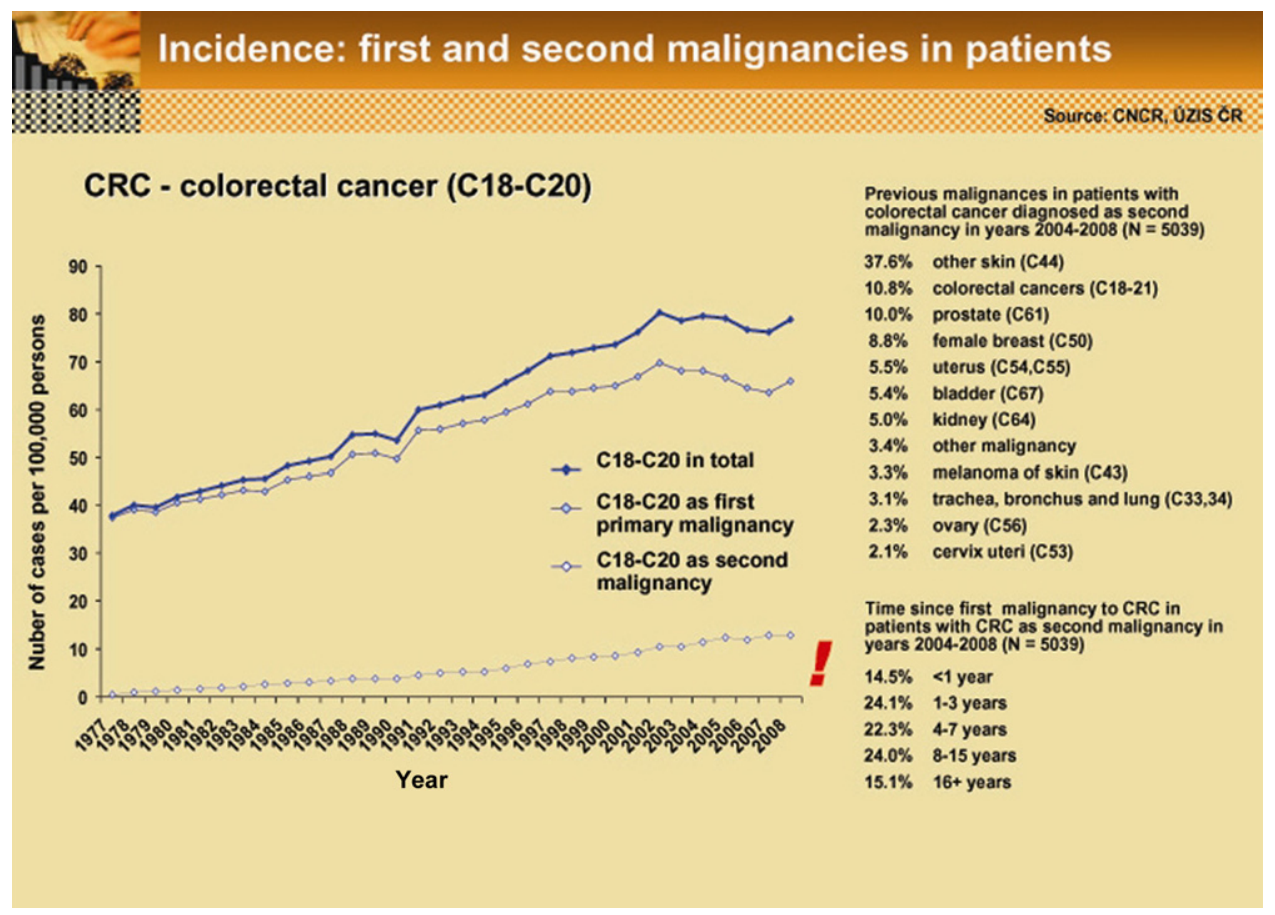

Fig. 1 - Incidence: first and second malignancies in patients with colorectal cancer. 


\section{Table 1 - Epidemiology of selected cancer diseases.}

\begin{tabular}{|c|c|c|c|c|c|c|c|c|c|c|c|c|}
\hline \multirow{3}{*}{$\begin{array}{l}\text { Location } \\
\text { of cancer }\end{array}$} & \multicolumn{6}{|c|}{ Whole population } & \multicolumn{6}{|c|}{ Population 70+ years } \\
\hline & \multicolumn{2}{|l|}{$\begin{array}{l}\text { Incidence } \\
(2004-2008)\end{array}$} & \multicolumn{2}{|l|}{$\begin{array}{c}\text { Mortality } \\
(2004-2008)\end{array}$} & \multicolumn{2}{|c|}{$\begin{array}{l}\text { Prevalence (at } \\
31.12 .2008 \text { ) }\end{array}$} & \multicolumn{2}{|l|}{$\begin{array}{l}\text { Incidence } \\
(2004-2008)\end{array}$} & \multicolumn{2}{|l|}{$\begin{array}{c}\text { Mortality } \\
(2004-2008)\end{array}$} & \multicolumn{2}{|c|}{$\begin{array}{l}\text { Prevalence (at } \\
31.12 .2008 \text { ) }\end{array}$} \\
\hline & $\begin{array}{l}\text { Number of } \\
\text { cases per } \\
\text { year }\end{array}$ & $\begin{array}{l}\text { Crude } \\
\text { rate per } \\
100,000\end{array}$ & $\begin{array}{l}\text { Number of } \\
\text { cases per } \\
\text { year }\end{array}$ & $\begin{array}{l}\text { Crude } \\
\text { rate per } \\
100,000\end{array}$ & $\begin{array}{c}\text { Number of } \\
\text { cases }\end{array}$ & $\begin{array}{c}\text { Crude } \\
\text { rate per } \\
100,000\end{array}$ & $\begin{array}{c}\text { Number of } \\
\text { cases per } \\
\text { year }\end{array}$ & $\begin{array}{c}\text { Crude } \\
\text { rate per } \\
100,000\end{array}$ & $\begin{array}{c}\text { Number of } \\
\text { cases }\end{array}$ & $\begin{array}{c}\text { Crude } \\
\text { rate per } \\
100,000\end{array}$ & $\begin{array}{l}\text { Number of } \\
\text { cases per } \\
\text { year }\end{array}$ & $\begin{array}{l}\text { Crude } \\
\text { rate per } \\
100,000\end{array}$ \\
\hline $\begin{array}{l}\text { Colon and } \\
\text { rectum } \\
\text { (C18-C20) }\end{array}$ & 7939 & 76.9 & 4103 & 39.6 & 45,866 & 438.2 & 3975 & 384.7 & 2481 & 240.2 & 14,623 & 1392.4 \\
\hline Pancreas (C25) & 1871 & 18.1 & 1781 & 17.3 & 1584 & 15.1 & 958 & 92.8 & 962 & 93.1 & 500 & 47.6 \\
\hline $\begin{array}{l}\text { Head and neck } \\
\text { (C00-C14.C30- } \\
\text { C32) }\end{array}$ & 1880 & 18.2 & 974 & 9.4 & 11,390 & 108.8 & 410 & 39.7 & 249 & 24.1 & 1699 & 161.8 \\
\hline Lung (C34) & 6383 & 61.8 & 5517 & 53.5 & 10,139 & 96.9 & 2536 & 245.5 & 2387 & 231.0 & 2406 & 229.1 \\
\hline $\begin{array}{l}\text { Melanoma of } \\
\text { skin (C43) }\end{array}$ & 1839 & 17.8 & 337 & 3.3 & 18,743 & 179.1 & 596 & 57.7 & 156 & 15.1 & 3312 & 315.4 \\
\hline $\begin{array}{l}\text { Female breast } \\
\text { (C50) }\end{array}$ & 6074 & $115.1^{\mathrm{a}}$ & 1833 & $34.7^{\mathrm{a}}$ & 58,719 & $1101.4^{\mathrm{a}}$ & 1939 & $297.7^{a}$ & 983 & $150.8^{a}$ & 11,041 & $1675.3^{\mathrm{a}}$ \\
\hline $\begin{array}{l}\text { Female } \\
\text { reproductive } \\
\text { system } \\
\text { (C53-C56) }\end{array}$ & 4022 & $76.2^{\mathrm{a}}$ & 1540 & $29.2^{\mathrm{a}}$ & 48,029 & $900.9^{a}$ & 1218 & $187.0^{\mathrm{a}}$ & 725 & $111.3^{\mathrm{a}}$ & 5691 & $863.5^{\mathrm{a}}$ \\
\hline Prostate (C61) & 4952 & $98.1^{b}$ & 1366 & $27.1^{b}$ & 28,412 & $553.2^{b}$ & 2612 & $684.6^{b}$ & 1070 & $280.3^{b}$ & 12,995 & $3322.7^{b}$ \\
\hline Kidney (C64) & 2785 & 27.0 & 1110 & 10.8 & 18,166 & 173.5 & 1099 & 106.4 & 591 & 57.2 & 4012 & 382.0 \\
\hline Stomach (C16) & 1658 & 16.1 & 1282 & 12.4 & 4845 & 46.3 & 881 & 85.3 & 746 & 72.2 & 1556 & 148.2 \\
\hline
\end{tabular}


Elder age categories are underrepresented in most of clinical studies. A comprehensive review and analysis is provided by Kazmierska. ${ }^{2}$

In the absence of sufficient data on tolerance and results of anticancer therapy in senior citizens clinicians frequently indicate less intensive treatment in comparison with general

\section{Colon and rectum (C18-C20)}

Incidence

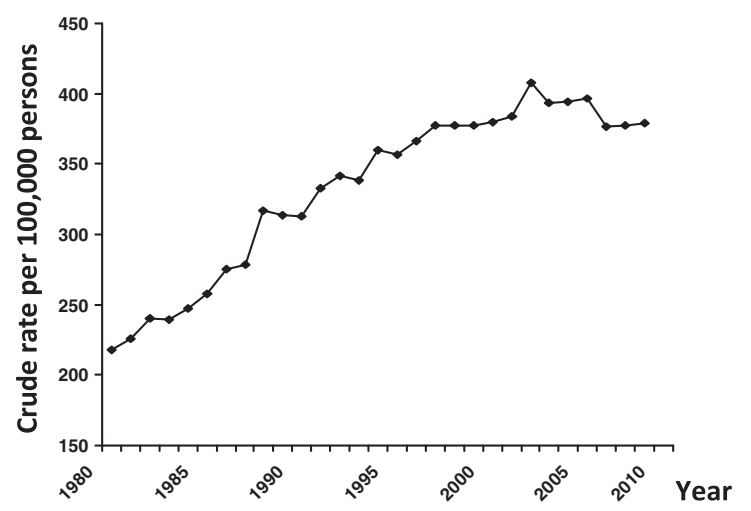

Head and neck (CO0-C14,C30-C32)

Incidence

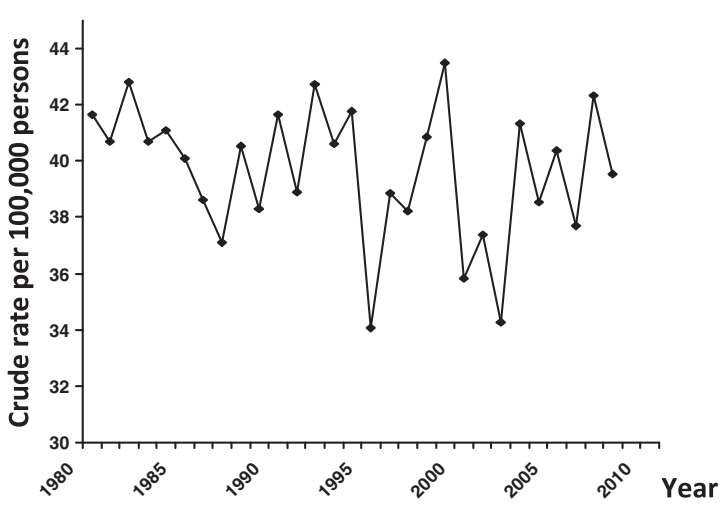

Melanoma of skin (C43) Incidence

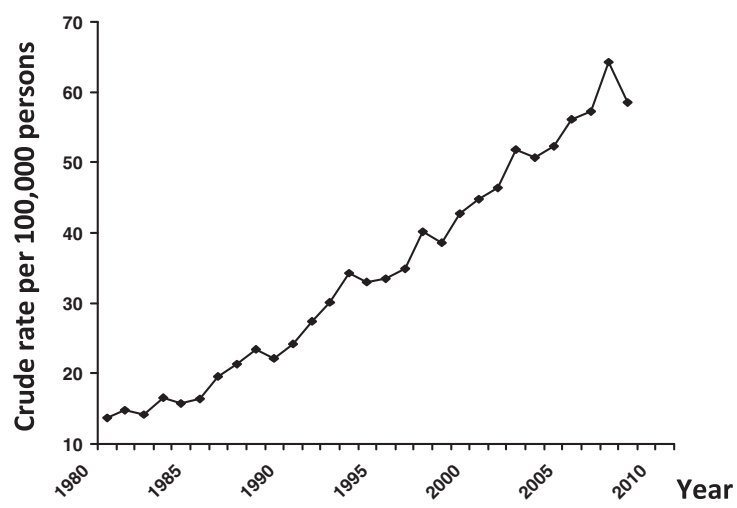

guidelines. But age itself is not contraindicative of curative oncological treatment and older patients with good performance status and minimal comorbidity may the same benefit from an aggressive approach as younger patients, although more complex supportive and psychological care is frequently necessary. In Particular, radiotherapy can be delivered
Pancreas (C25)

Incidence

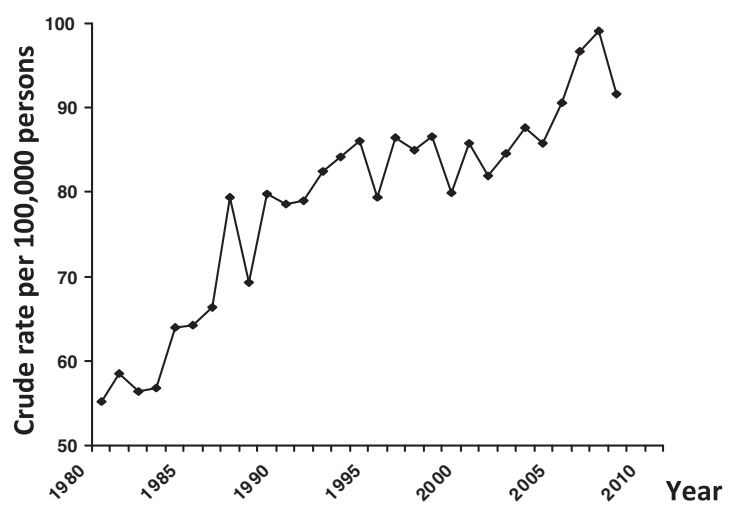

Lung (C34)

Incidence

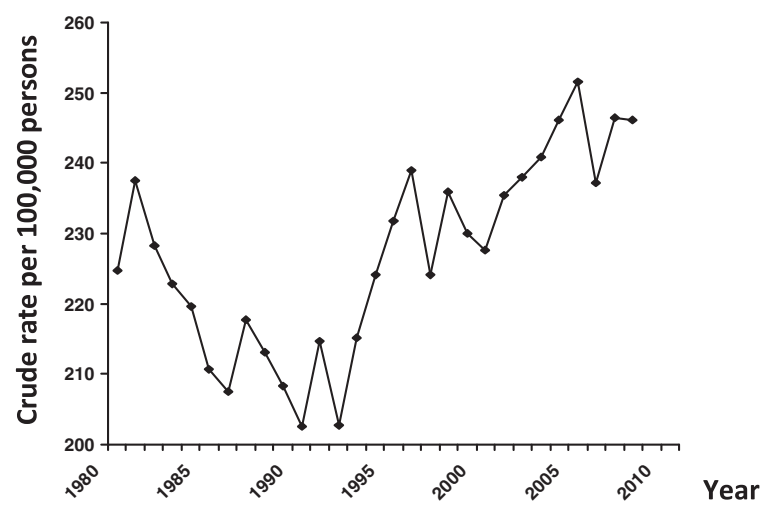

Female breast (C50)

Incidence

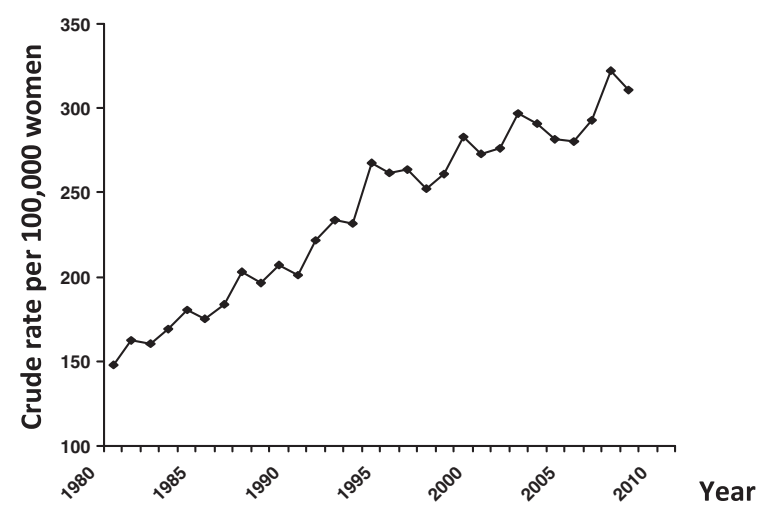

Fig. 2 - Crude incidence range in age category $70+$. 
Female reproductive system (C53-C56) Incidence

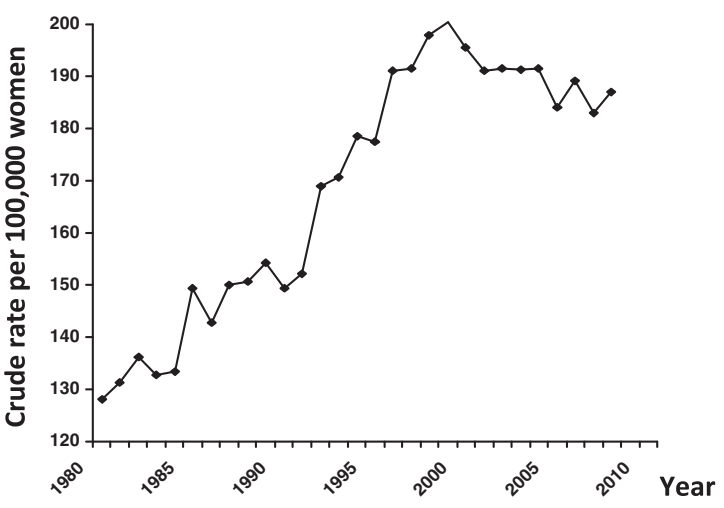

\section{Kidney (C64)}

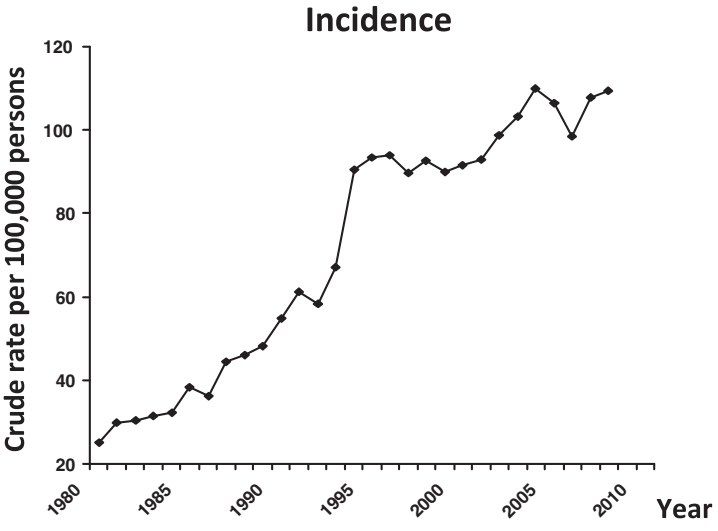

Prostate (C61)

Incidence

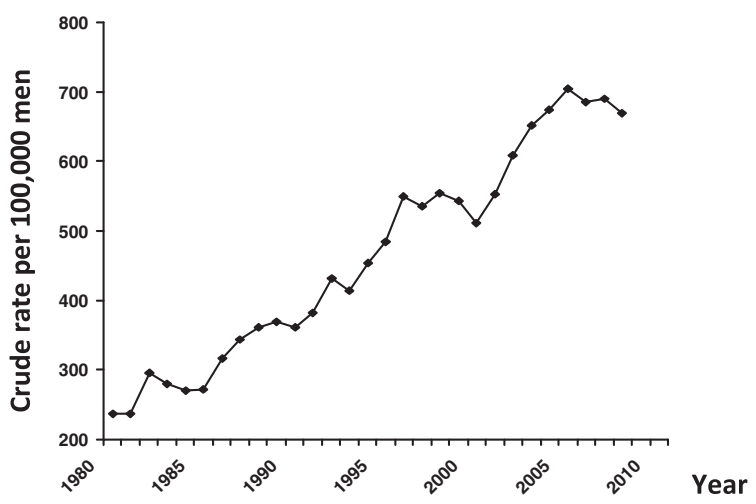

Stomach (C16)

Incidence

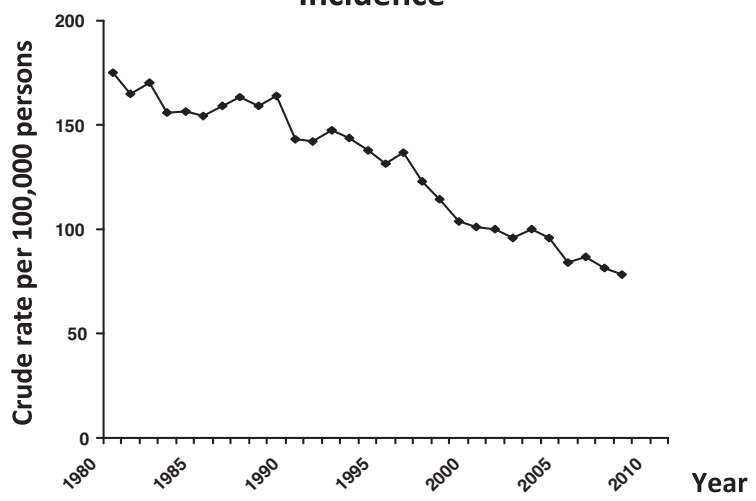

Fig. 2 - (Continued).

in radical doses, which is supported by the experience of Soumarova ${ }^{3}$ and the review by Gugic and Strojan ${ }^{4}$. Site effects of radiotherapy and the influence on the life quality of patients should be considered. ${ }^{5}$ On the other hand, radiotherapy can substitute systematic treatment in some cases. ${ }^{6}$

Undertreatment of elder patients with breast cancer may be connected with poorer outcome compared to younger subjects, ${ }^{7}$ but Tesarova $^{8}$ presents evidence that older but otherwise healthy women can tolerate standard adjuvant chemotherapy very well and also surgery should not be omitted. The radiotherapy can be delivered in more patient friendly schedules than the common practice offers. ${ }^{9-11}$

One of the very important conditions of both radical and palliative treatment of elderly patients is adequate nutrition,

$\begin{array}{lllllllllll}0 \% & 10 \% & 20 \% & 30 \% & 40 \% & 50 \% & 60 \% & 70 \% & 80 \% & 90 \% & 100 \%\end{array}$

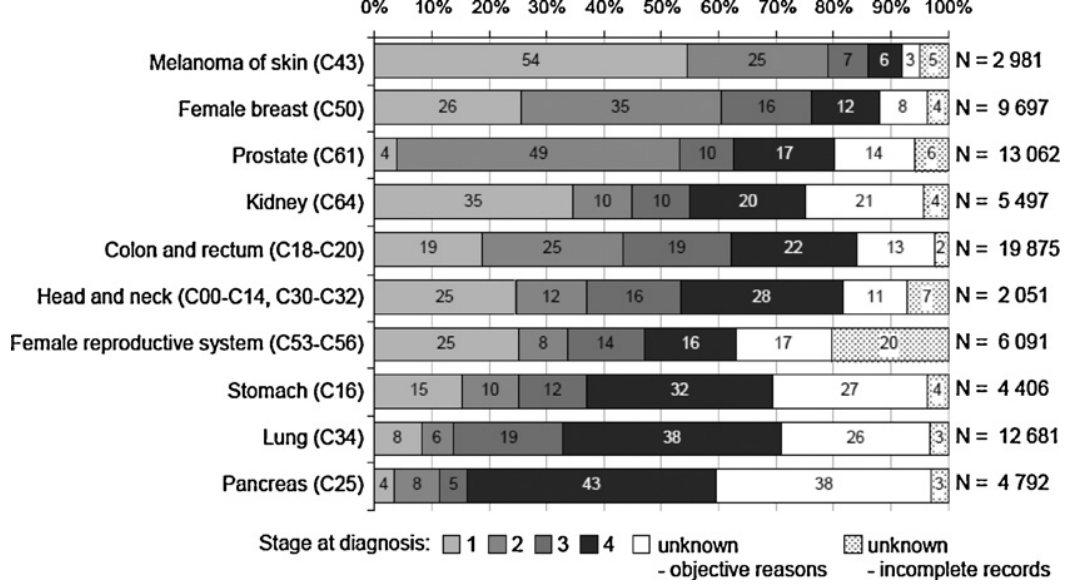

Fig. 3 - Stages of the disease at diagnosis in patients aged 70+, period 2004-2008. Diagnoses are sorted according to proportion of stages 1 and 2. 
which can improve the treatment results and quality of life. ${ }^{12}$ Zadak $^{13}$ offers a complex insight into the pathogenesis of tumor cachexia and sarcopenia and recommendations for nutritional care of elderly patients.

On the other hand it is important to identify frail patients who will not derive benefit from radical procedures and their quality of life will be impaired. Development of simple and reliable tools for tailoring of oncological treatment is an object of contemporary research. ${ }^{14}$

A part of the patients progress despite treatment or are in a condition that makes an anticancer treatment impossible. The practical experience with a system of palliative care is described by Slovacek et al. ${ }^{15}$ An adequate social support seems to be a very important aspect of the complex treatment of senior patients. ${ }^{16}$

One of most difficult decisions in oncology is related to the end of life of oncological patients. The most pressing questions are discussed by Trivedi. ${ }^{17}$

Like in other fields of medicine, the necessity of better understanding the problems of elderly patients also emerged in oncology. In the year 1999 the International Society of Geriatric Oncology (SIOG) was established with a goal to guarantee progress and practical achievements for geriatric patients and to grant them equal chance of effective treatment as for younger patients. It seems desirable to create oncogeriatric working groups by oncological departments allowing complex treatment of seniors, including internal, nutritive, rehabilitation and psychological aspects and to establish a subspecialisation of oncology - gerontooncology. We hope, that the present issue will contribute to this effort.

\section{Conflict of interest}

None declared.

\section{Financial disclosure}

None declared.

\section{REFERENCES}

1. Cardia J, Calcada C, Pereira H. Treatment of lung cancer in the elderly: influence of comorbidity in toxicity and survival. Rep Pract Oncol Radiother 2011;16:45-8.

2. Kazmierska J. Do we protect or descriminate? Representation of senior adults in clinical trials. Rep Pract Oncol Radiother 2013;18:6-10.

3. Soumarova R. Long term results of HDR brachytherapy in men older than 75 with localized carcinoma of the prostate. Rep Pract Oncol Radiother 2013;18:11-5.
4. Gugič J, Strojan P. Squamous cell carcinoma of the head and neck in the elderly. Rep Pract Oncol Radiother 2013;18:16-25.

5. Fernandez G, Pocinho R, Travancinha C, et al. Quality of life and radiotherapy in brain metastases patients. Rep Pract Oncol Radiother 2012;17:281-7.

6. Strojan P. Role of radiotherapy in melanoma management. Radiol Oncol 2010;44:1-12.

7. Ovcaricek T, Frkovic AG, Matos E, et al. Triple negative breast cancer - prognostic factors and survival. Radiol Oncol 2011;45:46-52.

8. Tesarova P. Breast cancer in the elderly - should it be treated differently. Rep Pract Oncol Radiother 2013;18:26-33.

9. Kacprowska A, Jassem J. Hypofractionated radiotherapy for early breast cancer: review of phase III studies. Rep Pract Oncol Radiother 2012;17:66-70.

10. Algara M, Arenas M, De las Penas Aloisia Bayo E. Radiation techniques used in patients with breast cancer. Results of a survey in Spain. Rep Pract Oncol Radiother 2012;17:122-8.

11. Kacprowska A, Jassem J. Partial breast irradiation techniques in early breast cancer. Rep Pract Oncol Radiother 2011;19:213-20.

12. Cacicedo J, Casquero F, Martinez-Indart L. Detection of risk factors that influence weight loss in patients undegoing radiotherapy. Rep Pract Oncol Radiother 2012;17:269-75.

13. Zadak Z. Disease specific substrates in cancer cachexiareality and anticipation. Rep Pract Oncol Radiother 2013;18:34-43.

14. Kazmierska J. Assessment of health status in elderly patients with cancer. Rep Pract Oncol Radiother 2013;18:44-8.

15. Slovacek L, Kopecký J, Priester P, Slováčková B, Slánská I, Petera J. Palliative care among elderly cancer patients: own experience. Rep Pract Oncol Radiother 2013;18:49-52.

16. Bernard D, Zysnarska M, Adamek R. Social support for cancer - selected problems. Rep Pract Oncol Radiother 2010;15:47-50.

17. Trivedi S. Physician perspectives on resuscitation status and DNR order in elderly cancer patients. Rep Pract Oncol Radiother 2013;18:53-6.

Jiří Petera*
Department of Oncology and Radiotherapy, University Hospital
Hradec Králové, Czech Republic

Ladislav Dušek Institute of Biostatistics and Analyses, Masaryk University, Brno, Czech Republic

* Corresponding author at: Department of Oncology and Radiotherapy, University Hospital in Hradec Králové, Sokolska 581, 50005 Hradec Králové, Czech Republic. Tel.: +420 495832 176; fax: +420 495832081

E-mail address: petera@fnhk.cz (J. Petera)

1507-1367/\$ - see front matter (c) 2012 Greater Poland Cancer Centre. Published by Elsevier Urban \& Partner Sp. z o.o. All rights reserved. http://dx.doi.org/10.1016/j.rpor.2012.11.001 